\title{
Accounting for State Intervention: The Social Histories of “Beneficiaries”
}

\author{
Monika Krause, University of Kent
}

Published in: Qualitative Sociology, 2010, 33 (4): 533-547

\begin{abstract}
How does the state imagine the people? In what ways does it come to know the targets of its policies? This paper examines the transformation of the state through a focus on the visions implied in tools and practices of results-based management in state bureaucracies. When scholars have discussed the state's vision or imagination they have often critically examined how the state constructs aggregates of the population as a whole. But an emphasis on or critique of aggregation can only be the beginning of understanding the multiple and sometimes contradictory ways in which people are imagined in governance today. Results-based management has created a new way in which the state imagines people. In some policy arenas citizens have been turned into "beneficiaries" through the practices of state managers. Beneficiaries differ from citizen in a number of ways: Citizens are thought to benefit from policies with broad goals; beneficiaries are shown to benefit from specific interventions. Citizens are owed service; beneficiaries are selected for intervention if it suits specific funding priorities. Citizens are the origins of politics and the end of policies; beneficiaries are a means to an organization's success.
\end{abstract}

Keywords: State, Citizenship, Bureaucracy, Evaluation, New public management, Logframe, Logic model, Neoliberalism 


\section{Introduction}

How does the state imagine the people? In what ways does it come to know the citizenry, or the targets of its policies? What kind of information does it gather, and what kind of information does it not gather? How does the state think about itself, its relationship to the citizen, and its successes or failures? How is the vision of the state changing? When scholars have discussed the state's vision or imagination they have often critically examined how the state constructs aggregates of the population as a whole, or, how it collects information about the individual citizen. But an emphasis on or critique of aggregation or individualization can only be the beginning of understanding the multiple, changing, and sometimes contradictory ways in which people are imagined in governance today.

This paper analyses the vision and the knowledge implied in and produced by the practices and tools of results-based management in state bureaucracies. I examine the origins and implications of these tools for three cases. Firstly, the use of Planning, Programming and Budgeting (PPB) during the Kennedy and Johnson administration in the United States. Secondly, the use of the logframe, a prominent tool in development work and humanitarian relief. Thirdly, the logic model, a tool used in public sector and non-profit programming. These three versions of results-based management share important features: They are introduced to further accountability and efficiency. Reforms treat states as though they were business organizations, and rely on the expertise of business managers. They see the state as a means to an end. They focus activity towards clearly defined and discrete goals 
and encourage planning by results, rather than input. Results-based management focuses on measurable outcomes on the level of the single organization. It enables comparison among units and thus also frees managers from commitment to any particular part of the organization: the data collection it requires provides justification for cutting spending and reducing programming.

These reforms also differ in interesting ways: PPB is a case that shows the early origins of these reforms and the progressive motivations behind it. The logframe shows the implications of results-based management when applied by organizations in the absence of a commitment to specific populations. The logic model allows us to explore the contemporary relevance in domestic policy.

Results-based management, I want to show, has created a new way in which the state imagines "the people", the human targets of its policies. Tools like the logframe or the logic model imagine people as part of the result of a policy intervention, as “beneficiaries”. The rhetoric of citizenship and the population persists, but in some policy arenas citizens have become primarily beneficiaries in the practices of state managers. The figure of the beneficiary contrasts with the figure of the citizen in a number of ways. Citizens are thought to benefit from policies with broad goals; beneficiaries are shown to benefit from specific interventions. Citizens are owed service; beneficiaries are selected for intervention if it suits specific funding priorities. Citizens are the origin of politics and the end of policies; beneficiaries are a means to an organization's success and are transformed to be shown as results.

The rise of results-based management provides insights into the process of neo-liberal transformation more generally. Results-based management did not originate in the new 
right ideologies of the 1980s, but has a much longer history. It was partly driven by progressives with high hopes and noble intentions to make government more rational and effective. It was not imposed on the state by market actors, but was partly fuelled by practical concerns arising within state bureaucracies. As a case of reform, in which institutional form has come to matter relatively independently of the substantive vision of the people who helped create it and in which institutional form has come to matter relatively independently of the content of policy, it points at dilemmas that might be applicable to rationalizing reform and improvement in modernity more broadly.

\section{The Transformations of the State}

Scholars have raised the question how the state is changing in the current era (Sassen 1998, Shaw 2000, Campbell and Pedersen 2001, Peck and Tickell 2002, Brenner and Theodore 2002, Brenner 2004, Sassen 2006). This marks a departure from on the one hand, abstract discussions of what the state is and, on the other hand, a debate on whether or not the state had lost control, influence, or authority through the changes associated with neoliberalism and globalization.

The object of inquiry in this intellectual project is cast widely, and it includes in an analysis of the state a recognition of the political role of policy networks, experts, non-governmental organizations and quasi-governmental organizations. This is due to a theoretical shift and due to a historical diagnosis: Theoretically, scholars drawing on Marx, Foucault, and feminists have made the point that we need a broader category of "the state", or "the political" or "governance" to be able to analyze the way the state itself draws the line between state and non-state (Jessop 1990, 2007 Mitchell 1991, Vogel 1998). This is all the 
more important as, empirically, scholars of administration have diagnosed a shift from government to governance, from bureaucracies to networks (Rhodes 1994, 1996, 2007). NGOs are thus considered a part of the state (Brand et al. 2001).

\section{The People as Seen by the State}

While the pioneering efforts to bring the state back into social scientific analysis framed the state in opposition to culture (Skocpol 1979, Evans, Rueschemeyer and Skocpol 1985), recently scholars have encouraged us to think about the state itself as a cultural phenomenon (Steinmetz 1999). In this, the sociology of the state, is meeting a renewed interest among political scientists and scholars of public administration for culture (Hood 1998, Bevir and Rhodes 2001, 2003, 2007) and an interest among anthropologists for the state and for policy (Shore and Wright 1997, Nugent and Vincent 2004). This work has alerted us to new dimensions of the object 'state', and thereby new possible dimensions of variation and change. It is not just institutions, or policies that can vary but also ways of interpreting, knowing and imagining.

With regard to the question how states see the population, scholars have emphasized two aspects: firstly, the construction of aggregates of the population; secondly the construction of individual citizens. We have classic accounts of how the modern state created the 'population' as an aggregate object of concern in the context of public health and biopolitics, with the use of statistics (Foucault 1978, 2008; Hacking 1990). Timothy Mitchell has examined how "the economy was created” by Keynesian economists moving into the state (Mitchell 1998). James Scott has examined various large-scale projects of 
“development” with regard to the abstractions it engenders (Scott 1998). Arjun Appadurai has examined the use of aggregates in the colonial state (Appadurai 1996, Kalpagam 2000). Scholars have also pointed out that the state's vision individualizes. Foucault has identified this tendency as a feature of the modern state's vision in general: Analyzing the metaphor of the shepherd and his flock, he writes "The shepherd directs the whole flock, but he can only really direct it insofar as not a single sheep escapes him. The shepherd counts the sheep; he counts them in the morning when he leads them to pasture, and he counts them in the evening to see that they are all there, and he looks after each of them individually (Foucault 2008: 128). This process of individualization might take on specific neoliberal forms, which is analyzed as "governmentality", or as "consumerism in the public sector". An emphasis on or critique of aggregation and individualization, can only be the beginning of understanding the multiple, changing, and sometimes contradictory ways in which numbers are used in governance today and in which the state encounters people. Aggregates of the (national) population not only coexist today with multiple ways of evoking of individuals or consumers (Gray 2007, Clarke 2006, Clarke, Smith and Vidler 2006), but also with different kinds of numbers. For example, aggregate measures now operate on a global level, as evidenced by the Millennium Development Goals (UNDP 2001). Resultsbased management creates quite a new set of numbers. Any unit of government is under pressure to not only set goals but to aim for measurable results. Policies focus not on aggregate information about populations but about data on specific groups of people being intervened upon. People become not just objects of bureaucratic apparatuses as individuals but are selected in groups, and become part of a result to be maximized. 


\section{Following the Tools}

Much discussion in political life focuses on the ideological content of a policy. Some work on the cultural sociology and the anthropology of the state has also been done focusing on the level of shared meanings, ideology, or discourse.

Following a long tradition in the sociology of culture, I focus on the practices of managers

instead. This directs our attention from the politics of the content of policy to the politics of planning and delivery, trough which any sets of values will be filtered.

I focus here on the practices of state-planners in state and quasi-state organizations because these practices allow us to see something unique. Very important work has focused on the micro level of local delivery and implementation. But the level of delivery only deals with those who are actually intervened upon. Planning mediates between the rhetoric of politicians and the actual delivery. This level is a key level for deciding what the state does and what the state does not do, where it intervenes and where it does not intervene. Work in the social studies of science and technology (Latour 1987), and the anthropology of policy (Strathern 2000), as well as critical studies of accounting (Preston, Cooper Coombs 1992, Power 1997, Miller and Hopwood 1994, Miller 2001, Miller and O’Leary 2007, Chwastiak 2001), has drawn our attention to the implications of the tools and technologies used. Tools shape what people see and know and what they do. Following the tools and their uses allows us to see ways in which different empirical sites of different reach are linked in practice. 
Particularly relevant to this paper is work diagnosing the rise of new cultures of auditing, accountability, and performance measurement (Power 1997, Strathern 2000); organizations are increasingly asked to provide an account of themselves in terms of formalized procedures and rituals. I want to explore here in particular the implications not just of the pressure to be accountable in terms of performance and procedure but, more specifically, the pressure to be accountable in terms of results for specific people outside the organization.

\section{The Long History of Results-Based Management and the Hope for Rational}

\section{Government}

Much writing on "new public management” broadly speaking, both celebratory and critical, dates its rise to the early 1980s. Scholars attribute it to the power of "new right” ideologies in the Reagan and Thatcher era. They see it as an incursion of the market into the state and will sometimes emphasize the influence of private sector actors such as the lobbying efforts of management consultants (Boston et al. 1991).

For a fuller understanding of these reforms and their implications we can also situate them in a longer and in a more complicated history. While of course the early 1980s mark a significant point in this history, it goes back much longer. Christopher Hood points at the patterns in arguing about the good state that recur across historical contexts (1998). Utilitarianism as a political philosophy implies results-based management. In the 20th century in the US, results-based reforms date back at least until the Budget and Accounting Act of $1921 .^{1}$

\footnotetext{
${ }^{1}$ I thank a reviewer of this paper for this insight.
} 
While the right was generally supportive of these measures, huge impetus was added by progressives with high hopes and noble intentions to make government more rational and effective. It is progressive administrations in the UK and the US who made the first decisive steps towards results-based management. In the UK, Labor PM Harold Wilson initiated a review of the civil service when the left came to power in 1964 after 13 years (Saint-Martin 1998). In the US as well, administrative reform was pushed forward in the early 1960s by the left-of-center administration of John F. Kennedy (Gross 1965, 1969, Schick 1966, 1971, Chwastiak 2001).

In both cases progressive administrations were mistrustful of state bureaucracies, which they perceived as having served elites, and which they wanted to make accountable on behalf of a broader coalition of voters whom they claimed they represented. In both cases, these administrations had high hopes for what rational government could achieve in terms of social reform. In both cases, these governments had limited resources to pursue their visions.

While business provided important models to draw on, these management tools in their origins traveled across the boundary of state and market and back. The biography of a reformer like McNamara illustrates this point: McNamara was trained in economics, mathematics and business administration, served in the Air Force's Office of Statistical Control during the war and became the first non-family member to serve as president of the Ford Motor Company. McNamara was brought into the defense department as a business man and he brought with him experts in business management. But, perhaps more significantly, he was a modernizer in both worlds - business and the military - putting to work technical expertise independently of tradition, upbringing, or life experience. These 
reforms are not only imposed from the outside but are also fuelled by concerns arising for some professionals inside the state (see also Humphrey, Miller and Scapens 1993). Administrative reforms have come in spurts and have nowhere fully achieved their vision. But since the middle of the $20^{\text {th }}$ century, whenever reformers attempted to improve public bureaucracies - regardless of their specific ideological orientation or motivation - they drew on some version or other of results-based management.

The repertoire of results-based management has set the framework within which politicians responded to critics on the left and on the right. It has also been the framework within which ministers and civil servant defended expenses towards external audiences. Results-based management has taken varying forms. Since the performance budgeting promoted by the Hoover commission of 1949 (Nguyen 2007), and McNamara’s PPB, Richard Nixon introduced management by objectives, inspired by business management ideas following Drucker (1954). Jimmy Carter championed zero-base budgeting. During the 80s and 90s, so-called new public management ideas gained influence in varied ways in a number of western countries (Hood 1996).

An important variable distinguishing variants of results-based management is the scale on which it is implemented. Results-based management makes no assumptions as to the scale on which activities are integrated into an organization. Should the whole government be seen as one business organization? Or every government agency? Or should it be implemented on the level of agency's units? Or on the level of an agency's projects? New public management distances itself from "old public management”, dismissing earlier forms of reform as overly bureaucratic and aiming for too large a scale. There is some indication, however, that the determinant of the scale of implementation is not so much to 
be found on the level of ideology but is rather a question of inner-organizational powerrelationships. Reforms were more likely to be lasting when integrated in line with existing power relationships (Schick 1971, 1973). In organizations where centralized rationalization failed, lower-level managers may have found its rhetoric advantageous in dealing with those below them.

I examine the origins and implications of these tools for three cases. Firstly, the use of Planning, Programming and Budgeting during the Kennedy and Johnson administration in the United States; secondly, the use of the logframe, a prominent tool in development work and humanitarian relief; thirdly, the logic model, a tool used in public sector and non-profit programming.

PPB is a case that shows the origins and logic of these reforms for an early case. The logframe is widely used in development aid and humanitarian relief, an area where the term beneficiary is most widely used and where we can see some of its implications in the absence of a complimentary discourse of citizenship. The case of the logic model allows us to explore the contemporary relevance in domestic policy.

\section{The case of PPB}

Planning, Programming and Budgeting (PPB) was introduced under the administrations of John F. Kennedy and Lyndon B. Johnson. PPB was a pioneering effort to focus bureaucracies on measurable results. It included many elements shared by later versions of results-based management and is instructive as a case both with regard to its motivations and its consequences. 
The Kennedy and Johnson Administrations came at a time of vibrant critique of social inequalities and high hopes were placed in social reform. There was renewed interest in channeling resources towards addressing social problems, in the south, and in the cities. As a contemporary observed: "There was confidence in the ability of government to eradicate hard-core social and human problems and in its ability to specify and reach long-range objectives. A few years earlier President Kennedy had predicted a moon landing in this decade. Why not set concrete targets for a wide range of social endeavors?” (Schick 1969: 144).

There had been huge electoral gains for Democrats, but incoming progressives were mistrustful of the hierarchies they inherited from the previous government. Johnson assumed the presidency at a moment, when the right and the left were critical of government bureaucracies. The anti-authoritarian left questioned the state-apparatus as oppressive and unaccountable. Policy-makers began to anticipate the end of the post-war expansion of the economy, and the balance of payment deficit was beginning to impose constraints. Kennedy and Johnson aimed to reign in public spending (Major 2008). Planning, Programming and Budgeting (PPB) was first introduced in the defense department by Robert McNamara in 1961. McNamara revolutionized the way the defense department drew up its budget. In the 1940s and 1950 officials reported their budget line by line according to the type of expense such as personnel, stationary, operations, maintenance, or construction. This would be done separately for each military division be it army, navy, or air force. PPB linked budgeting with planning. Each budget was now done according to the goal and measurable outcome the resources were designated for. According to the department of defense PPB “emphasized objectives—PPBS focused less 
on the existing base and annual incremental improvements to it, and more on the objectives and long-term alternative means for achieving them.” In addition, "by means of programming, PPBS instilled a process that essentially defines a procedure for distributing available resources equitably among the many competing or possible programs.” (Department of Defense n.d.)

According to Alain Enthoven, McNamara’s Assistant Secretary of Defense, “the key to the programming system is decision-making by program elements and major programs; this is, by the outputs of the department rather than by the inputs. A program element is an integrated activity combining men, equipment, and installations whose effectiveness can be related to our national security objectives. The list included b-52 wings, infantry battalions, and combatant ships, taken together with all the equipment, men, installations and supplies required to make them an effective military force. The program elements are assembled into major programs which contain interrelated elements, which closely complement each other or are close substitutes for each other and which must therefore be considered together in arriving at top-level decisions”(quoted in Chwastiak 2001: 507).

PPB was associated with the hope of making public administration more rational: Allen Schick contrasted the promises of systems politics represented by PPB with the old process politics: "In process politics the contestants tend to view the options from the perspectives of their established positions (existing legislation, last year's budget, the "base” etc). Theirs is a retrospective bias. Budgeting is treated as the process of financing existing commitments and of creating some new commitments (the increments). System politics tends to have a prospective bias; budgeting is regarded as the allocation of money to attain some future value (the outcome, or objective. This year's budget, in system terms, is an 
installment in buying that future.” (Schick 1969: 138). For Schick, a political scientist, PPB would provide the solution to all that was wrong with politics as described by pluralist political science.

As Chwastiak analyses very clearly, for Kennedy and McNamara PPB had many advantages (Hammond 1967, Chwastiak 2001). It allowed them to sidestep military expertise and assume control over spending. Traditionally, each division would say what was needed and how much was needed based on "security needs" - which was difficult to challenge for a civilian secretary of defense. The new budgeting device allowed McNamara to pass over the military expertise of staff with battleground experience and privilege the expertise of his own training as well as that of his team of systems analysts. It put him and his experts in a unique position to compare and scrutinize existing programs. It allowed McNamara to assume control over spending, and limit spending commitments. "Because decision-making under PPB was based on comparisons which spanned traditional service lines, the final budget could only be put together by the secretary of Defense. As Chwastiak argues "not only did he withhold the ultimate yes or no decision from the military but in addition he dictated to the armed services the information that would serve as a basis for his decision” (Chwastiak 2001:510).

PPB enables a systematic comparison of programs based on an analysis that related the achievement of certain goals to cost. This comparison conceives of any particular program as expendable, and it was the program managers who were providing data that might then be used to justify the cutting of expenditure.

In the Defense Department, most decisions involved how to best secure safety for all Americans based on hypothetical conflict scenarios; thus, the comparison among projects in 
general did not involve comparisons among specific people to be served. But the tools of system analysis could be used to compare programs that directly related to different populations, and in some cases, decisions that implied a choice between different populations to be protected were considered. Some of the analyses invited by the Department of Defense's Office for systems analysis concerning the US' priorities regarding its extended commitments during the Cold War fall into that category. ${ }^{2}$ Some of the planning of civil protection within the United States also involved the comparison of costs for protecting specific parts of the territory and with that specific parts of the population. ${ }^{3}$

\section{The Logframe}

It is in development aid and humanitarian relief that the term "beneficiaries" is most commonly used; today managers in donor governments and aid agencies take it for granted to call those targeted by their interventions and aid projects "beneficiaries", but the concept has a fairly recent history that is intimately linked with the history of a specific planning tool, the logframe.

${ }^{2}$ See for example Draft Presidential Memo on NATO Strategy and Force Structure, January 7, 1969, and Draft Presidential Memo on Asia Strategy and Force Structure, February 1, 1969, Papers of Alain Enthoven, Box 4, Draft Presidential Memos, 1968-1969, Tabs AF, LBJ Library.

${ }^{3}$ See for example Memorandum for the President, “Civil Defense” First Draft, October 28, 1963, Papers of Alain Enthoven, Box 1, Vol. 1, Strategic Offensive and Defensive Forces, Part 1, LBJ Library. 
The "logframe", this matrix of four rows and four columns is the core of logical framework analysis, a planning approach that aims to help managers establish a coherent project

---- Illustration 1 about here -----

The logframe was conceived for United States Agency of International Development by a management consultancy firm in the late 1960s. Since then, logical framework analysis has been widely adopted by other institutional donors in different versions (Steigerwald 1995, Nakabayashi 2000).

Two trends within USAID created the conditions for the development of logical framework analysis in the late 1960s: Firstly, a shift in focus from economic development to a focus on the needs of the poor, and secondly, efforts to create better tools to evaluate the work the agency itself was doing. In this case, efforts to make the state serve people more directly and make it more responsible meant that ambitious aims for all were abandoned in favor of focusing on specific results for specific selected people.

In the 1950s and 1960s, the focus of aid was on economic development, and, in particular, on economic growth. It was hoped that growth in turn would lead to a greater standard of living and lower inequality. The role of aid was seen principally as a source of capital to trigger growth through higher investment. USAID emphasized large infrastructural projects. Development experts favored investments in modern, industrial sectors that might help developing nations "catch-up” with industrialized nations. According to Thorbecke "clearly the adoption of GNP growth as both the objective and the yardstick of development was directly related to the conceptual state of the art in the 1950s. The major theoretical 
contribution which guided the development community during that decade were conceived within a one-sector, aggregate framework and emphasized the role of investment in modern activities (Thorbecke 2000: 20).

By the mid 1960s, the optimism of the first years following independence for the new African and Asian states had been dampened; growth - when it happened - did not seem to have the desired results. There was now more inequality than before; dependency theory pointed at the structural heritage of colonialism, arguing that biased terms of trade would prevent former colonies from catching up. Within conventional development economics, experts sought a better understanding of the role of different sectors and subsectors; rethinking their earlier celebration of all modern sectors and their dismissal of agriculture. During the 1970s, development aid turned to a focus on basic needs and on helping the poor directly.

During its early years, before USAID committed to a project, it would conduct a feasibility study, and cost-benefit analyses. The measure of success was GDP growth on a national level - and later, to some extent national unemployment figures. The choice was partly driven by available data: "The reliance on aggregate models was not only predetermined by the ... conceptual state of the art but also by the available data system which in the 1950s consisted almost exclusively of national income accounts”(Thorbecke 2000: 22). Both GDP growth and unemployment figures operate at some distance from any concrete activities by agents of development.

Foreign aid had always been under special pressure to justify expenses by critical audiences at home in general and congress in particular. When doubts grew about the overly optimistic assumptions of an aid policy based on modernization theory, this pressure rose. 
USAID was admonished to spend more time evaluating and assessing their own efforts. A report by consultancy Booz-Allen and Hamilton concluded in 1965: “It has often been said that AID has an inadequate memory. Evaluation reports on projects in process or completed are rare. ... in spite of substantial evaluation efforts, frequently on an ad-hoc basis it is still true that AID has not yet developed a systematic process to appraise the consequences and results of its program operations and to exploit the rich accumulated experience by the agency” (quoted in Schick 1993: 27).

Certain features of USAID made it harder to consistently evaluate USAID efforts. One was "vague planning: "in general there was no clear picture of what a project would look like, if it were successful - the objectives were multiple and not clearly related to project activities”. The paper also bemoans “unclear management responsibilities”. “There were many important factors outside the control of project managers not stated as such (external factors) which made it difficult on the part of the project managers to accept responsibilities for outcomes” (quoted in Deutsche Stiftung für Internationale Entwicklung 2004). These two factors also meant staff could not reasonably be held responsible for results; they could not with their own efforts guarantee good evaluations for their own projects. According to the business management doctrines of the time, this presents a problem for staff as well as for management trying to motivate staff (see Boltanski and Chiapello 2006). Evaluation appeared “as an adversary process: in the absence of clear project targets evaluators tended to use their own judgment as to what they thought was "good" and bad" (quoted in Deutsche Stiftung für Internationale Entwicklung 2004). Evaluation results would become the basis for arguments about what was desirable and undesirable in general instead of fostering constructive actions for project improvement. If staff feels their own 
appraisals are tied to the evaluations of their projects, they may push to focus the project evaluation on only the processes their own effort can control.

Consider the following example of a logical framework matrix. It was developed by Oxfam and provided by the European Union’s Office for Humanitarian Affairs in order to guide NGOs who are considering applying for funding for relief work (ECHO 2004).

The three-page document describes a water and sanitation project for refugees in a refugee camp. It covers three areas central to this sector of relief work, proposing to dig latrines, build wells, and train people in personal hygiene practices. The planning related to sanitary facilities is reproduced in illustration 2.

---- Illustration 2 about here -----

The logframe states the overall goal of the project in the top left corner and then seeks to establish a link between higher level goals, such as "improved health” and more concrete, lower level goals or projected results, such as that "refugees have access to appropriate sanitary facilities”. Finally, the matrix links higher level goals to concrete activities such as building “temporary defecation areas” or latrines, and training latrine attendants.

Logframe planning invites managers to clearly state the conditions upon which a project's progress depends. What assumptions are managers relying on in their planning? What external factors need to be in place so that the goals of the project can be met? In this case, the agency relies on other agencies to provide services, and on government border guards to improve security. If the government denies access to NGO staff, the NGO will not be able 
to deliver. If refugees leave the camp, the NGO's latrines will not contribute to reaching the health goals for them.

The logframe focuses our attention on measurable results for a specified target population in a specific time frame. The matrix specifies costs for the project and it relates these costs to outcomes. In an accompanying memo, ECHO advises agency staff to be as specific as possible in this procedure: "It is also useful to split costs by result if this is possible so that the actual costs of each result can be determined from the logical framework with personnel and direct support costs apportioned on a proportional basis” (ECHO 2004). In the example provided, costs for sanitation, water, and hygiene are thus listed separately. In these ways, the logframe helps to make the project comparable to other projects. The proposed project helps specific people, who, one assumes would otherwise be without the water and sanitation facilities they need. It is also a water and sanitation package for 8000 people for $€ 578$ 974, which can be compared to a similar package for another group of people.

The logframe is often criticized within the NGO community (e.g. Wallace, Crowther and Sheperd 1993). It is portrayed as a device that bureaucratizes spontaneous generosity. It is important to note, however, that the shift to results-based management facilitated the move to bring in NGOs for implementing state policy. Logical Framework Analysis links broad policy goals with discrete projects; this makes it easier for governments to cut pieces out of large programs and hire an NGO to do the work.

It also gives an organization like USAID considerable flexibility in how much to spend. The accountability is no longer regarding the overall goals or the overall population but regarding specific beneficiaries and specific project aims chosen by the donor agency and 
NGOs. Donor agencies want to be seen to be doing “something”. Aid NGOs seek to assist selected beneficiaries, these are thus an end of their activities; but beneficiaries are also a means to an end. Agencies must produce specific beneficiaries to exchange them against project funding from donor agencies.

\section{Logic Models}

Tools like the logframe have emerged in domestic governance as well, under various names such as performance framework or logic model. The logic model today is used by public sector organizations as well as NGOs working in a range of fields- ranging from energy provision, to HIV prevention, and domestic violence projects to anti-poverty programs for at-risk-youth (McLaughlin and Jordan 1997, Wholey 1979, Collins et al. 1999, W.K. Kellog foundation 1998).

Like the logframe, the logic model asks managers to focus on discrete goals, name inputs, activities, outputs, outcomes, impact (W.K. Kellog foundation 1998) and establish a connection between these. Like the logframe, it allows for accounting where profit is not the main criterion, by including non-monetary benefits in a measurable way.

---- Illustration 3 about here ----

It was first used by evaluators (Wholey 1979). Charged with assessing what organizations were doing, evaluators found it useful to chart an ex-post rational version of what the organization should be doing and compare it to reality. In this way, they could use the logic 
model to guide their research and make the criteria for their judgments and recommendations explicit.

But it has become used not just in analyzing organizational activities ex-post but also as a tool to guide program planning and implementation. In the United States, the Government Performance and Results Act of 1993 put new pressure on those receiving public money to tell a story in terms of measurable results. We haves seen that these efforts to rationalize have a long history. More than 40 years after the introduction of PPB, observers of program planning could still write: "Program managers are not as familiar with describing and measuring outcomes as they are with documenting inputs and processes” (McLaughlin and Jordan 2004: 1).

Citizens are not the output of the project. But if we follow the logic of program planning, somewhere between output and impact, citizens are included as beneficiaries. As McLaughlin and Jordan state “The relationship between resources and results cannot happen without people -- the customers served and the partners who work with the program to enable actions to lead to results. Placing customers, the users of a product or service, explicitly in the middle of the chain of logic helps program staff and stakeholders better think through and explain what leads to what and what population groups the program intends to serve” (McLaughlin and Jordan 2004: 2)

Or as Montague explains, “The inclusion of reach in logic models allows people to clearly distinguish events which happen as part of program processes normally called outputs (e.g. number of publications, events, interventions and other tangible things under the control of a program) from outcomes or impacts which relate to the reaction, satisfaction, knowledge gain and behavior changes and benefits occurring in target groups” (Montague 1998) 
The logic model does not determine a lack of coverage but it is compatible with a lack of coverage. Policy proposals in conjunction with logic models produce evidence for results and achievements while hiding the fact that coverage is not achieved.

This is not the case in all policy areas to the same extent. But consider, for example, recent trends in urban policy: The Single Regeneration Budgets, launched in 1994 in the UK, aim to foster urban regeneration. Here, local authorities have to competitively bid for funds in cooperation with the voluntary sector and the business community that then provide support for community activities, housing and employment training on a project-basis. Services are rendered to people not as citizens but as beneficiaries of what happened to be a successful bid from specialized organizations. For the purpose of reporting and evaluation, beneficiaries are counted and advertised as results (e.g. Svensson de la Cruz and Krause 2002a, 2000b).

\section{Conclusion}

When reformers have tried to make state bureaucracies serve the people more directly, they have tried to focus budgeting and planning on results. For results to be counted they had to be measurable and they had to be attributable to the specific unit of planning. For outputs to become results, a specific group of people had to be reached and transformed.

With the emphasis on results, a new category emerges, that of the beneficiary of a policy. Beneficiary is not just another word for the citizen. A citizen is someone who participates in politics and is then entitled to claim a share in the collective achievement, be it economic growth or welfare rights. A beneficiary is part of a selected group that is meant to benefit 
from a specific policy intervention. A citizen is the origin and the end of policy, a beneficiary is part of the result.

If the citizen benefits he or she does so as part of a community of others with the same entitlements. The problem of course is that in reality he or she might see very little actual benefit. The beneficiary is demonstrated to have been transformed by the intervention. The problem here is that a government might choose to select some projects here and there to advertise results to higher levels in the reporting hierarchy while infrastructure is undermined and citizens do not have any rights at all qua being citizen. With the emphasis on results per unit of organization, the commitment to any specific group of the populations becomes contingent.

When a policy is announced with reference to goals and values, we should direct our attention not only to the politics of its content but also to the politics of planning and delivery, trough which any sets of values will be filtered.

We cannot, of course, expect the use of these planning tools to proceed without friction, such as friction triggered by the encounter of the tool with the specificity of specific policy areas and with specific people. This friction could be the subject of further and comparative research.

\section{Works Cited:}

Appadurai, Arjun. 1996. Modernity at Large: Cultural Dimensions of Globalization. Minneapolis: University of Minnesota Press. 
Bevir, Mark and R A W Rhodes. 2003. Interpreting British Governance. London: Routledge.

Bevir, Mark and R.A.W. Rhodes. 2007. “Politics as Cultural Practice.” Political Studies Review 6 (2): 170-77.

Boltanski, Luc and Eve Chiapello. 2006. The New Spirit of Capitalism. London: Verso.

Boston, Jonathan, John Pallot, June Martin and Pat Walsh. 1991. Reshaping the State: New Zealand's Bureaucratic Revolution. Oxford: Oxford University Press.

Brand, Ulrich, Alex Demirovich, Christoph Goerg, Joachim Hirsch (eds). 2001. Nichtregierungsorganisationen in der Transformation Des Staates. Münster: Westfälisches Dampfboot.

Brenner, Neil and Nik Theodore (eds). 2002. Spaces of Neoliberalism: Urban Restructuring in Western Europe and North America. Oxford: Blackwell.

Brenner, Neil. 2004. New State Spaces: Urban Governance and the Rescaling of Statehood. Oxford: Oxford University Press.

Campbell, John L. and Ove K. Pedersen (eds). 2001. The Rise of Neoliberalism and Institutional Analysis. Princeton: Princeton University Press.

Chwastiak, Michele. 2001. “Taming the Untamable: Planning, Programming and Budgeting and the Normalization of War.” Accounting, Organizations and Society 26(6):501519.

Clarke, John 2006. “Consumers, Citizens or Clients: Politics, Policy and Practice in the Reform of Social Care.” European Societies 8(3): 423-442. 
Clarke, John, Nick Smith and Elizabeth Vidler. 2005. “Creating Citizen-Consumers: inequalities and instabilities.” Social Policy Review 17. Bristol: The Policy Press.

Collins, Janet, Deborah Rugg, Laura Kann, Stephen Banspach and Lloyd Kolbe. 1996. “Evaluating a National Program of School-Based HIV Prevention.” Evaluation and Program Planning 19(3):209-218.

Department of Defense. n.d.“Planning, Programming, Budgeting and Execution. The Historical Context.” Available at: http://www.defenselink.mil/comptroller/icenter/budget/histcontext.htm (accessed $11 / 19 / 2009)$

Deutsche Stiftung fuer Internationale Entwicklung. 2004. "Introduction to the Logical Framework Approach (LFE) for GEF-Financed Projects.” Available at: www.undp.org.gef/05/documents/me/AnnexIII_LogicalFrameworkApproach_A_Re ader04.doc. (accessed 11/19/2009)

Drucker, Peter F. 1954. The Practice of Management. New York: Harper \& Brothers.

ECHO. 2004. "Humanitarian actors - Framework Partnership Agreement. Annex 1. Single Form. Logical Framework Matrix.” Available at: http://ec.europa.eu/echo/about/actors/archives_fpa2003_en.htm [accessed $11 / 9 / 2008]$.

Evans, Peter B, Dietrich Rüschemeyer, and Theda Skocpol (eds). 1999. Bringing the State Back In. Cambridge: Cambridge University Press.

Foucault, Michel. 1978. The History of Sexuality. Vol. 1. New York: Pantheon Books. 
Foucault, Michel. 2008. The Birth of Biopolitics: Lectures at the College De France, 19781979. London: Palgrave Macmillan.

Gray, Andrew. 2007. "Relationships of Consumption: Citizens, Clients and Customers of Public Services”. Memorandum to Public Administration Select Committee, House of Commons, United Kingdom. On file with author.

Gross, Bertram M. 1965. “McNamaran Management.” Public Administration Review 25(3):259-261.

Gross, Bertram M. 1969. “The New Systems Budgeting.” Public Administration Review 29(2):113-137.

Hacking, Ian. 1990. The Taming of Chance. Cambridge: Cambridge University Press.

Hammond, Paul. 1968. “A Functional Analysis of Defense Department Decision-Making in the McNamara Administration.” American Political Science Review 62(1):57-69.

Hood, Christopher. 1996. "Exploring Variations in Public Management Reform of the 1980s.” In Hans A. G. M. Bekke, James L. Perry and Theo A. J. Toonen (eds) Civil Service Systems in Comparative Perspective. Bloomington: Indiana University Press, pp. 268-287.

Hood, Christopher. 1998. The Art of the State: Culture, Rhetoric, and Public Management. Oxford: Clarendon Press.

Humphrey, Christopher, Peter Miller and Robert W. Scapens. 1993. "Accountability and 'Accountable Management' in the UK Public Sector." Accounting, Auditing and Accountability Journal 6(3): 7-29. 
Jessop, Bob. 1990. State Theory: Putting the Capitalist State in Its Place. University Park: Pennsylvania State University Press.

Jessop, Bob. 2007. State Power: A Strategic-Relational Approach. Cambridge: Polity.

Kalpagam, Umamaheswaran. 2000. "Colonial Governmentality and the 'economy'.” Economy and Society 29(3):418-438.

Latour, Bruno. 1987. Science in Action. How to follow scientists and engineers through society. Cambridge: Harvard University Press.

LBJ Library Enthoven Papers. n.d.. Papers of Alain Enthoven.

Major, Aaron. 2008. "Hanging in the Balance: Global Capitalism and the American Welfare State.” Unpublished Ph.D.-Thesis. New York: New York University.

McLaughlin, J.B. and G.B. Jordan. 2004. Using Logic Models. Handbook of Program Evaluation 2, 7-32.

Miller Peter and Anthony G. Hopwood (eds) 1994. Accounting as Social and Institutional Practice. Cambridge: Cambridge University Press.

Miller, Peter and T. O’Leary. 2007. "Mediating Instruments and Making Markets: Capital Budgeting, Science and the Economy." Accounting, Organizations and Society. 32 (7/8): 701-734.

Miller, Peter. 2001. "Governing by Numbers: Why Calculative Practices Matter", Social Research. 68/2: 379-396.

Mitchell, Timothy. 1991. "The Limits of the State: Beyond Statist Approaches and their Critics.” American Political Science Review 85(1):77-96. 
Mitchell, Timothy. 1998. "Fixing the Economy.” Cultural Studies 12(1):82-101.

Montague, Steve. 1998. Build Reach into Your Logic Model. Performance Management Network, http://www.pmn.net/library/build_reach_into_your_logic_model.htm [accessed 11/20/2009].

Nakabayashi, Saeko. 2000. The Japanese Version of Project Cycle Management. The Hague: Institute of Social Studies.

Nguyen, Hoang-Phuong. 2007. Performance Budgeting: Its Rise and Fall. Syracuse: Maxwell School of Citizenship and Public Affairs

Nugent, David and Joan Vincent. 2004. A Companion to the Anthropology of Politics. Oxford: Blackwell.

Peck, Jamie and Adam, Tickell.2002. “Neoliberalizing space.” Antipode 34 (3): 380-404.

Power, Michael. 1997. The Audit Society: Rituals of Verification. Oxford: Oxford University Press.

Preston, Alistair M. and David J. Cooper and Rod W. Coombs. 1993. "Fabricating budgets: A study of the production of management budgeting in the national health service.” Accounting, Organizations and Society 17 (6): 561-593.

Rhodes, R. A. W. 1994. "The Hollowing Out of the State: the Changing Nature of the Public Service in Britain.” Political Quarterly 65(2):138-138.

Rhodes, R. A. W. 1996. “The New Governance: Governing without Government.” Political Studies 44(4):652-667. 
Rhodes, R.A.W. 2007. “Understanding Governance: ten years on.” Organization Studies, 28 (8): 1243-1264.

Saint-Martin, Denis. 1998. "Management Consultants, the State, and the Politics of Administrative Reform in Britain and Canada.” Administration \& Society 30(5):533-568.

Sassen, Saskia. 1998. “The de-facto transnationalization of immigration policy.” In Christian Joppke (ed.) Challenges to the Nation State. Immigration in Europe and the United States. Oxford: Oxford University Press, pp 49-86.

Sassen, Saskia. 2006. Territory, Authority, Rights: From Medieval to Global Assemblages. Princeton: Princeton University Press.

Schick, Allen. 1966. “The Road to PPB: The Stages of Budget Reform.” Public Administration Review 26:243-258.

Schick, Allen. 1969. “Systems Politics and Systems Budgeting.” Public Administration Review 29(2):137-151.

Schick, Allen. 1971. “The Road to PPB: The Stages of Budget Reform.” In Resource Allocation in Agricultural Research, ed. Walter L. Fishel. Minneapolis: University of Minnesota Press.

Schick, Allen. 1973. “A Death in the Bureaucracy: The Demise of Federal PPB.” Public Administration Review 33:146-156.

Schick, Allen. 1993. USAID Program and Operations Assessment Report No. 4. A Performance-Based Budgeting System for the Agency for International Development. Arlington: USAID. 
Scott, James C. 1998. Seeing Like a State. How Certain Schemes to Improve the Human Condition Have Failed. New Haven: Yale University Press.

Shaw, Martin. 2000. Theory of the Global State: Globality as an Unfinished Revolution. Cambridge: Cambridge University Press.

Shore, Chris and Susan Wright. 1997. Anthropology of Policy. London: Routledge.

Skocpol, Theda. 1979. States and Social Revolutions: A Comparative Analysis of France, Russia, and China. Cambridge: Cambridge University Press.

Steigerwald, Volker. 1995. "Recent Developments in GTZ's Use of the ZOPP.” In Tool for Project Management and People-Driven Development: Proceedings of the INTRAC and South Research Workshop on LFA and OOIP, Leuven, Belgium, 16-18 May 1994, Oxford: INTRAC.

Steinmetz, George (ed). 1999. State/Culture: State-Formation after the Cultural Turn. Ithaka: Cornell University Press.

Strathern, Marilyn (ed) 2000. Audit Cultures. Anthropological studies in accountability, ethics and the academy. London: Routledge.

Svensson de la Cruz, Helena and Monika Krause. 2002a. "An evaluation of the SRB South Leytonstone Agenda 21 Neighbourhood Development Programme.” London: CIS Commentaries Nr.111.

Svensson de la Cruz, Helena and Monika Krause. 2002b. “Click. The Youth Technology Centre. An Evaluation.” London: CIS Commentaries Nr.110.

Thorbecke, Erik. 2000. "The Evolution of the Development Doctrine and the Role of Foreign Aid, 1950-2005.” In Finn Tarp and Peter Hjertholm (eds) Foreign Aid and 
Development: Lessons Learnt and Directions for the Future. London: Routledge, pp. $17-47$.

UNDP. 2001. Human Development Report 2000. New York: Oxford University Press.

Vogel, Ulrike. 1998. “The State and the Making of Gender: Some Historical Legacies.” In Vicky Randall, and Georgina Waylen (eds) Gender, Politics and the State. London and New York: Routledge, pp. 29-44.

W. K. Kellogg Foundation. 1998. Leaders Against Family Violence: A Fictionalized Account of a W.k. Kellogg Foundation-Sponsored Cluster Evaluation. Battle Creek: W.K. Kellogg Foundation.

Wallace, Tina, Sarah Crowther, and Andrew Shepherd. 1997. Standardising Development: Influences on UK NGOs' Policies and Procedures. Oxford: WorldView Publications.

Wholey, Joseph. 1979. Evaluation: Promise and Performance. Washington: Urban Institute.

List of Illustrations

1: Logical Framework, from FAO n.d

2: Logical Framework Matrix, from ECHO 2004

3: Logic Model, from United States Department of Transportation n.d. 
Illustration 1:

\begin{tabular}{||l|l|c|c||}
\hline \multicolumn{1}{|c|}{$\begin{array}{c}\text { Project } \\
\text { Structure }\end{array}$} & $\begin{array}{c}\text { Objectively } \\
\text { Verifiable } \\
\text { Indicators }\end{array}$ & $\begin{array}{c}\text { Means of } \\
\text { Verification }\end{array}$ & $\begin{array}{c}\text { Important } \\
\text { Assumptions }\end{array}$ \\
\hline Goal & & & \\
\hline Purpose & & & \\
\hline & & & \\
\hline Outputs & & & \\
\hline & & & \\
\hline Activities & & & \\
\hline
\end{tabular}


Illustration 2

\begin{tabular}{|c|c|c|c|c|}
\hline & Narrative descriptions & $\begin{array}{l}\text { Objectively verifiable } \\
\text { indicators }\end{array}$ & Sources of information & Risks and assumptions \\
\hline $\begin{array}{l}\text { Principal } \\
\text { objective }\end{array}$ & $\begin{array}{l}\text { The health status of refugees and local } \\
\text { villagers is improved. }\end{array}$ & & & \\
\hline $\begin{array}{l}\text { Specific } \\
\text { objective }\end{array}$ & $\begin{array}{l}\text { The target population have increased access to } \\
\text { and make optimal use of water and sanitation } \\
\text { facilities, and take action to protect } \\
\text { themselves against threats to public health. }\end{array}$ & $\begin{array}{l}\text { Target group uses facilities } \\
\text { and resources } \\
\text { appropriately, and safely. } \\
\text { Water and sanitation } \\
\text { facilities are effectively } \\
\text { managed by the target } \\
\text { community. }\end{array}$ & $\begin{array}{l}\text { Information from other } \\
\text { NGOs, focus group } \\
\text { discussions. Surveys. }\end{array}$ & $\begin{array}{l}\text { Conflict in the neighbouring } \\
\text { country does not spill over and } \\
\text { destabilize the host country. } \\
\text { The health centres set up by the } \\
\text { other INGO remain operational. } \\
\text { UNHCR continue to provide } \\
\text { sufficient food rations, shelter, } \\
\text { and blankets. }\end{array}$ \\
\hline Results & $\begin{array}{l}\text { 1. } 8000 \text { refugees have adequate, appropriate } \\
\text { and safe sanitary facilities within six months. }\end{array}$ & $\begin{array}{l}\text { Temporary defecation areas } \\
\text { set up and used } \\
\text { appropriately. } 400 \text { latrines } \\
\text { constructed and used } \\
\text { appropriately. Female } \\
\text { refugees use sanitation } \\
\text { facilities in safety. Latrines } \\
<50 \mathrm{~m} \text { from shelters } \\
\end{array}$ & $\begin{array}{l}\text { Monitoring visits to } \\
\text { camp. Latrine } \\
\text { monitoring forms. } \\
\text { Reports by latrine } \\
\text { assistants. Focus group } \\
\text { discussions with } \\
\text { women and girls. }\end{array}$ & $\begin{array}{l}\text { Government border guards are } \\
\text { able to improve security to } \\
\text { reduce/ prevent rebel raids. } \\
\text { Refugees stay in camp. }\end{array}$ \\
\hline Activities & $\begin{array}{l}\text { Result 1: Adequate sanitary facilities in the } \\
\text { camp. } \\
\text { Set up temporary defecation areas } \\
400 \text { gender-se } \\
\text { gregated latrines constructed in line with } \\
\text { international standards } \\
40 \text { latrine attendants trained and equipped } \\
\text { Construction of } 200 \text { gender-segregated } \\
\text { washing facilities } \\
\text { Construction of } 80 \text { community washing } \\
\text { facilities (laundry) } \\
\text { Consultation with female refugees to identify } \\
\text { suitable sites for sanitation facilities } \\
\text { Provision of potties for under-fives }\end{array}$ & $\begin{array}{l}\text { Means: } \\
\text { Defecation field kit. } \\
\text { Latrine digging kit. } \\
\text { Latrine squat plates. } \\
\text { Latrine superstructure } \\
\text { construction. } \\
\text { Training workshops. } \\
\text { Construction materials/ } \\
\text { labour } \\
\text { Maintenance equipment } \\
\text { Potties } \\
\text { Personnel } \\
\text { Direct support costs }\end{array}$ & $\begin{array}{l}\text { Costs } \\
\text { Breakdown per result: } \\
\text { Result 1: €191,896 } \\
\ldots\end{array}$ & $\begin{array}{l}\text { Construction materials remain } \\
\text { available in adequate amounts. } \\
\text { National Government gives NGO } \\
\text { registration to work in the } \\
\text { country. }\end{array}$ \\
\hline
\end{tabular}


Illustration 3

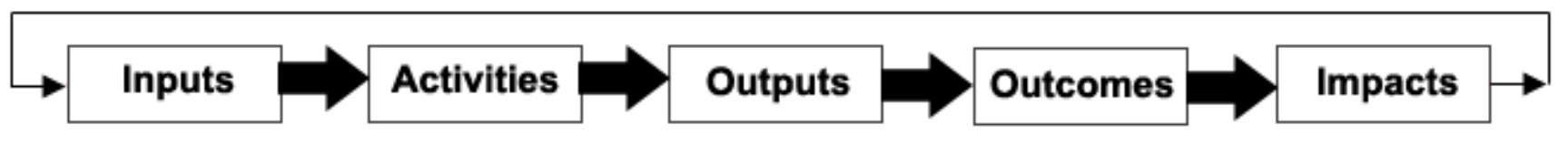

